Indonesian Journal of Islamic Psychology

Volume 1. Number 2, December 2019. p-ISSN 2685-1482, e-ISSN 2714-7576

website: http://e-journal.iainsalatiga.ac.id/index.php/ijip/index

\title{
Efektivitas Konseling Sebaya (Peer Counseling) dalam Menuntaskan Masalah Siswa
}

\section{Shofi Puji Astiti ${ }^{*}$}

Institut Agama Islam Negeri Surakarta, Indonesia

\begin{abstract}
Peer counseling is considered important because teenagers are more often told about the problems faced by peers compared to parents, as well as teachers in schools. The research aims at (1) knowing the implementation of peer counseling in solving the problem of MAN Yogyakarta II students, (2). Finding out what factors impede and support the effectiveness of peer counseling in MAN Yogyakarta II. The study used a type of field research that focused on the process of implementing peer counseling in resolving student issued using descriptive analytical analyses. The results of the research could be concluded that the implementation of peer counseling in MAN Yogyakarta II used three stages, namely the selection of prospective advisors, questions and answered of prospective advisors, and arranged the implementation of peer counseling.
\end{abstract}

Keywords: peer counseling; student problems; school.

\begin{abstract}
Abstrak
Konseling sebaya dipandang penting karena remaja lebih sering diberi tahu masalah yang dihadapi teman sebaya dibandingkan dengan orang tua, maupun guru di sekolah. Penelitian ini bertujuan (1). Untuk mengetahui implementasi konseling sebaya dalam menyelesaikan masalah siswa MAN Yogyakarta II, (2). Untuk mengetahui faktor-faktor apa yang menghambat dan mendukung efektivitas konseling sebaya di MAN Yogyakarta II. Penelitian ini menggunakan jenis penelitian lapangan yang berfokus pada proses penerapan konseling sebaya dalam menyelesaikan masalah siswa dengan menggunakan analisis deskriptif analitik. Hasil penelitian dapat disimpulkan bahwa implementasi konseling sebaya di MAN Yogyakarta II menggunakan tiga tahap, yaitu pemilihan calon penasihat, tanya jawab calon penasihat, dan atur pelaksanaan konseling rekan.
\end{abstract}

Kata kunci: konseling sebaya; masalah siswa; sekolah.

*Corresponding Author

shofi.a5titi@gmail.com 
Pendahuluan

Di tengah tantangan menghadapi globalisasi, permasalahan siswa MAN dan sederajat semakin kompleks. Selain itu diilihat dari tingkat perkembangannya, siswa MAN dan sederajat sangat rentan terhadap permasalahan, begitu juga yang dialami siswa MAN Yogyakarta II. Kondisi ini menuntut semakin eksis dan profesional kerja guru BK ataupun konselor sekolah. Siswa MAN dan sederajat, sesuai dengan usia perkembangannya berada pada masa remaja. Pada masa ini, ketertarikan dan komitmen serta ikatan terhadap teman sebaya menjadi sangat kuat. Hal ini antara lain karena remaja merasa bahwa orang dewasa tidak dapat memahami mereka. Keadaan ini sering menjadikan remaja sebagai suatu kelompok yang eksklusif karena hanya sesamalah yang dapat saling memahami.

Sebagian (besar) siswa lebih sering membicarakan masalahmasalah serius mereka dengan teman sebaya, dibandingkan dengan orang tua dan guru pembimbing. Masalah yang sangat seriuspun (misalnya, hubungan seksual, kehamilan di luar nikah, dan keinginan melakukan aborsi) mereka bicarakan dengan teman sebaya, bukan dengan orang tua atau guru mereka. Kalaupun terdapat beberapa siswa yang akhirnya menceritakan kehamilan, atau hubungan seksual kepada orang tua atau guru pembimbing, biasanya karena sudah terpaksa (pembicaraan dan dalam upaya pemecahan masalah bersama teman sebaya mengalami jalan buntu). Dengan demikian konseling sebaya (peer counseling) dipandang penting karena berdasarkan pengamatan penulis sebagian besar remaja sering membicarakan permasalahan yang dialamin dengan teman sebaya dibandingkan dengan orang tua, pembimbing, atau guru di sekolah. Mencermati fakta tersebut, maka perlu dikembangkan layanan konseling yang dilakukan oleh tenaga non- 
profesional (siswa) di bawah pengawasan konselor profesional. Dalam terminology konseling, kegiatan saling bantu dan saling mendukung di antara sesama teman sebaya dalam menghadapi berbagai persoalan hidup dan atau dalam mengembangkan potensi diri disebut dengan konseling sebaya (peer counseling) (Erhamwilda, 2012). Sekolah juga merupakan lembaga peralihan yang mempersiapkan remaja untuk berpindah dari kehidupan keluarga yang tunduk kepada bimbingan dan perlindungan dengan kekuasaan orang tua, menuju kepada kehidupan masyarakat yang berdiri sendiri, yang penuh dengan berbagai macam persaingan (Tohirin, 2009).

Selama ini kita mengasumsikan bahwa yang bertugas untuk membantu mengatasi masalah remaja di sekolah adalah guru (BK). Di sisi lain, teman sebaya (peer counseling) juga dapat dijadikan sebagai konselor sebaya. Peran mereka dapat membantu mengatasi permasalahan yang sedang dihadapi temannya. Tetapi konselor sebaya harus terlebih dahulu dibekali berbagai keterampilan komunikasi dasar seperti: keterampilan mendengar aktif, keterampilan melakukan empati, dan keterampilan memecahkan masalah (problem solving) (Hunainah, 2012).

\section{Konseling}

Konseling adalah hubungan pribadi yang dilakukan dengan cara tatap muka antara dua orang. Di mana konselor harus memiliki kemampuan-kemampuan khusus untuk menggiring situasi belajar dan membentuk individu agar dapat memahami diri sendiri, keadaan sekarang dan kemungkinan keadaan dimasa depan (Hunainah, 2012). Menurut Natawidjaya (dalam Sukardi, 2000) konseling adalah suatu jenis pelayanan yang merupakan bagian terpadu dari bimbingan. 
Konseling dapat diartikan sebagai hubungan timbal balik antara dua orang individu, di mana konselor berusaha membantu yang lain (konseli) agar dapat memahami tentang dirinya sendiri untuk menghadapi masalah-masalah pada waktu yang akan datang. Konseling sebaya (peer counseling) ini dipandang cukup efektif jika diberikan oleh teman sebayanya sendiri. Para remaja ada kecenderungan untuk memiliki personal fable. Yaitu keyakinan bahwa hanya dia yang mengalami pengalaman unik, bukan orang dewasa lain. Oleh karena itu, penguatan melalui konseling sebaya (peer counseling) dipandang efektif untuk dilakukan (Suraneta, 2013).

Dari beberapa rumusan tentang pengertian konseling di atas, dapat disimpulkan bahwa konseling merupakan proses pemberian bantuan yang dilakukan melalui wawancara konseling oleh seorang ahli (disebut konselor) kepada individu yang sedang mengalami masalah (disebut konseli) yang bermuara pada teratasinya masalah yang dihadapi konseli untuk mencapai kesejahteraan hidupnya.

\section{Tujuan Konseling}

Tujuan utama konseling adalah memperbaiki sikap, persepsi, cara berfikir, keyakinan, serta pandangan konseli yang irrasional dan illogis menjadi rasional dan logis agar konseli dapat mengembangkan diri, meningkatkan aktualisasi dirinya seoptimal mungkin melalui perilaku kognitif dan afektif yang positif". Kemudian ditambahkan lagi bahwa konseling juga bertujuan untuk menghilangkan gangguan-gangguan emosional yang merusak diri sendiri seperti: benci, rasa takut, rasa bersalah, rasa cemas, sebagai konsekuensi dari cara berfikir dan sistem keyakinan yang keliru dengan jalan melatih dan mengajar untuk 
menghadapi kenyataan hidup secara rasional dan membangkitkan kepercayaan, nilai-nilai dan kemampuan diri.

Dari rumusan tentang tujuan konseling di atas dapat diambil makna bahwa konseling pada hakekatnya bertujuan untuk memberikan bantuan kepada konseli sehingga hubungan yang terjadi dalam konseling adalah merupakan "helping relationship" (hubungan yang bersifat membantu). Dalam proses pemberian bantuan ini berlangsung suasana yang menunjang pencapaian tujuan melalui pertalian antara kepribadian dan keterampilan konselor dengan konseli.

\section{Proses Konseling}

Langkah-langkah dalam konseling sebagai berikut:

a) Persiapan, meliputi: kesiapan fisik dan psikis konselor, tempat dan lingkungan sekitar, perlengkapan, pemahaman konseli dan waktu.

b) Rapport, yaitu menjalin hubungan pribadi yang baik antara konselor dan konseli sejak permulaan, proses, sampai konseling berakhir, yang ditandai dengan adanya rasa aman, bebas, hangat, saling percaya dan saling menghargai.

c) Pendekatan masalah, dimana konselor memberikan motivasi kepada konseli agar bersedia menceritakan persolan yang dihadapi dengan bebas dan terbuka.

d) Pengungkapan, dimana konselor mengadakan pengungkapan untuk mendapatkan kejelasan tentang inti masalah konseli dengan mendalam dan mengadakan kesepakatan bersama dalam menentukan masalah inti dan masalah sampingan, serta masalah yang dihadapi konseli sendiri maupun yang melibatkan 
pihak lain. Sehingga konseli dapat memahami dirinya dan mengadakan perubahan atas sikapnya.

e) Diagnostik, adalah langkah untuk menetapkan latar belakang atau faktor penyebab masalah yang dihadapi konseli.

f) Prognosa, adalah langkah dimana konselor dan konseli menyusun rencana pemberian bantuan atau pemecahan masalah yang dihadapi konseli.

g) Treatment, merupakan realisasi dari dari langkah prognosa. Atas dasar kesepakatan antara konselor dengan konseli dalam menangani masalah yang dihadapi, konseli melaksanakan suatu tindakan untuk mengatasi masalah tersebut, dan konselor memberikan motivasi agar konseli dapat mengembangkan diri secara optimal sesuai kemampuan yang dimilikinya.

h) Evaluasi dan tindak lanjut, langkah untuk mengetahui keberhasilan dan efektifitas konseling yang telah diberikan, berdasarkan hasil yang telah dicapai oleh konseli. Selanjutnya konselor menentukan tindak lanjut secara lebih tepat, yang dapat berupa meneruskan suatu cara yang sedang ditempuh karena telah cocok maupun perlu dengan cara lain yang diperkirakan lebih tepat (Wibowo, 1986).

\section{Konseling Sebaya (Peer Counseling)}

Menurut Carr 1981 (dalam Suwarjo, 2008) konseling sebaya merupakan suatu cara bagi para siswa (remaja) belajar bagaimana memperhatikan dan membantu siswa lain, serta menerapkannya dalam kehidupan sehari-hari. Sementara itu Tindall dan Gray (1985) mendefinisikan konseling sebaya sebagai suatu ragam tingkah laku membantu secara interpersonal yang dilakukan oleh individu non 
profesional yang berusaha membantu orang lain. (Erhamwilda, 2011). Menurut Tindall dan Gray (1985) konseling sebaya mencakup hubungan membantu yang dilakukan secara individual (one-to-one helping relationship), kepemimpinan kelompok, kepemimpinan diskusi, pemberian pertimbangan, tutorial, dan semua aktivitas interpersonal manusia untuk membantu atau menolong (Lestariningsih, 2009). Definisi lain menekankan konseling sebaya sebagai suatu metode, seperti dikemukakan Kan "Peer counseling is the use problem solving skills and active listening, to support people who are our peers". (Kan, 1996).

Meskipun demikian, Kan mengakui bahwa keberadaan konseling sebaya merupakan kombinasi dari dua aspek yaitu teknik dan pendekatan. Berbeda dengan Tindall dan Gray (1985), Kan membedakan antara konseling sebaya dengan dukungan sebaya (peer support). Menurut Kan peer support lebih bersifat umum (bantuan informal; saran umum dan nasehat yang diberikan oleh dan untuk teman sebaya); sementara peer counseling merupakan suatu metode yang terstruktur. Konseling sebaya merupakan suatu bentuk pendidikan psikologis yang disengaja dan sistematik. Konseling sebaya memungkinkan siswa untuk memiliki keterampilan guna mengimplementasikan pengalaman kemandirian dan kemampuan mengontrol diri yang sangat bermakna bagi remaja.

Secara khusus konseling sebaya tidak memfokuskan pada evaluasi isi, namun lebih memfokuskan pada proses berfikir, proses perasaan dan proses pengambilan keputusan. Dengan cara yang demikian, konseling sebaya memberikan kontribusi pada pengalaman yang dimiliki, yang kuat serta yang dibutuhkan oleh para remaja yaitu respect (Suranata, 2013). Menurut Willis teman sebaya adalah kelompok 
yang terdiri dari anak-anak yang memiliki usia, kelas dan motivasi bergaul yang sama atau hampir sama. Hal ini dinamakan peer group atau kelompok teman sebaya dapat membantu proses penyesuaian diri yang baik (Sofyan, 2010).

Ditambahkan pula oleh Santrock, teman sebaya adalah individu yang tingkat kematangan dan umurnya kurang lebih sama. (Busri, 2013). Sedangkan Varenhorst (1984) mendefinisikan konseling sebaya sebagai suatu upaya yang dapat memengaruhi perubahan (intervention) sikap dan perilaku yang cukup efektif untuk membantu siswa yang mengikuti pembekalan dalam menyelesaikan masalah diri mereka sendiri. Konseling sebaya pada dasarnya merupakan suatu cara bagi siswa belajar memperhatikan dan membantu siswa lain, serta menerapkannya dalam kehidupan sehari-hari.

\section{Hakikat dan Prinsip-Prinsip Konseling Sebaya}

Pada hakikatnya konseling sebaya adalah konseling bagi konseli dari konselor ahli dengan menggunakan perantara teman sebaya (counseling through peers). Dalam konseling sebaya, konselor sebaya adalah sahabat karena kemampuan dan kelebihan-kelebihan personalnya, mereka memperoleh pembekalan untuk secara bersamasama membantu dan mendampingi proses penyelesaian masalah perilaku seksual yang dihadapi teman-teman di sekolah.

Pada tataran tertentu, di mana siswa menjumpai hambatan dan keterbatasan kemampuan dalam membantu teman, para (konselor) teman sebaya dapat berkonsultasi kepada konselor ahli untuk memperoleh bimbingan. Konselor sebaya juga diharapkan dapat mengajak dan menyarankan teman yang membutuhkan bantuan untuk berkonsultasi langsung pada konselor ahli. Dengan kata lain, "konselor" 
teman sebaya adalah jembatan penghubung (bridge) antara konselor dengan (konseli). Fungsi bridging "konselor" teman sebaya berlaku dalam dua arti yaitu menjembatani layanannya, yaitu layanan konselor ahli kepada konseli, dan atau menjembatani konseli untuk bersedia datang guna memperoleh layanan dari konselor ahli.

Konselor sebaya yang telah mendapatkan pembekalan, direkrut dari sekolah mereka sehingga memungkinkan melakukan kontak yang spontan dan informal dalam aktivitas sehari-hari di sekolah. Kontakkontak yang demikian memiliki pengaruh yang ganda pada berbagai aspek dari siswa lainnya. Kontak-kontak tersebut juga dapat memperbaiki atau meningkatkan iklim sosial dan dapat menjadi jembatan penghubung antara konselor professional dengan para siswa yang tidak sempat atau tidak bersedia berjumpa dengan konselor.

Kontak-kontak yang terjadi dalam konseling sebaya dilakukan dengan memegang prinsip-prinsip sebagai berikut:

a) Informasi (termasuk masalah) yang dibahas dengan sesi-sesi konseling sebaya adalah rahasia. Dengan demikian apa yang dibahas dalam kelompok haruslah menjadi rahasia kelompok, dan apa yang dibahas oleh sepasang teman, menjadi rahasia bersama yang tidak boleh dibagikan kepada orang lain.

b) Harapan, hak-hak, nilai-nilai dan keyakinan-keyakinan "konseli" dihormati.

c) Tidak ada penilaian (judgment) dalam sesi konseling sebaya.

d) Pemberian informasi dapat menjadi bagian dari konseling sebaya, sedangkan pemberian nasihat tidak.

e) Teman yang dibantu "konseli" bebas untuk membuat pilihan, dan kapan akan mengakhiri sesi.

f) Konseling sebaya dilakukan atas dasar kesetaraan (equality). 
g) Setiap saat" konseli" membutuhkan dukungan yang tidak dapat dipenuhi melalui konseling sebaya, dia dialih tangankan kepada konselor ahli, lembaga, atau organisasi yang lebih tepat.

h) Kapanpun membutuhkan, konselor memperoleh informasi yang jelas tentang konseling sebaya, tujuan, proses, dan teknik yang digunakan dalam konseling sebaya sebelum mereka memanfaatkan layanan tersebut.

Selanjutnya prinsip-prinsisp diatas, dalam konseling sebaya juga berlaku prinsip bahwa segala keputusan akhir yang diambil "konseli" berada dalam tangan dan tanggung jawab konselor (Hunainah, 2011).

\section{Langkah-Langkah Pelaksanaan Konseling Sebaya}

Pelaksanaan konseling sebaya secara sederhana dalam prakteknya dapat dilakukan dalam beberapa tahap yaitu sebagai berikut:

a) Tahap awal konseling sebaya (waktu: 30 menit)

1) "Konselor" sebaya mendengarkan secara aktif permasalahan yang disampaikan konseli sebaya.

2) "Konselor" sebaya mengenali dan menetapkan jenis masalah yang dihadapi konseli sebaya.

3) "Konselor" sebaya melakukan penjajakan alternatif bantuan untuk mengatasi masalah konseli sebaya.

4) "Konselor" sebaya menegosiasikan kontrak dengan konseli sebaya.

b) Tahap kerja konseling sebaya (waktu: 60-120 menit)

1) "Konselor" sebaya melakukan empati sambil menjelaskan dan mengeksplorasi masalah empati sambil menjelajahi dan mengeksploirasi masalah yang sedang dihadapi konseli sebaya. 
2) "Konselor" sebaya membangun afeksi positif konseli sebaya dalam menghadapi permasalahan seksualitas.

3) "Konselor" sebaya melatih konseli sebaya untuk membiasakan bertindak secara konstruktif dalam menghadapi masalah seksualitas.

4) "Konselor" sebaya menjaga agar hubungan konseling selalu terpelihara.

5) "Konselor" sebaya melakukan alih tangan (referal) dan konferensi kasus (case conference) jika diperlukan kepada konselor ahli.

c) Tahab akhir konseling sebaya (waktu: 30 menit).

1) "Konselor" sebaya menanyakan keadaan konseli sebaya tentang pikiran dan perasaannya setelah menjalani konseling sebaya.

2) "Konselor" sebaya menanyakan manfaat yang didapat dari konseling sebaya.

3) "Konselor" sebaya bersama konselor ahli mengamati perubahan sikap positif konseli sebaya dalam menghadapi masalah perilaku seksual yang dialaminya.

Pelaksanaan konseling sebaya diperkirakan membutuhkan waktu antara 150-180 menit yang berlangsung dalam 4-5 kali pertemuan. Untuk efektivitas layanan bantuan, jadwal pertemuan konseling sebaya dilaksanakan 2-3 kali dalam seminggu, dengan demikian dalam kurun waktu 2-3 minggu, kegiatan layanan konseling sebaya oleh "konselor" sebaya kepada seorang konseli sebaya selesai. Selanjutnya "konselor" sebaya bersama konselor ahli dapat melakukan evaluasi keberhasilan pemberian layanan konseling sebaya (Hunainah, 2011). 
Evaluasi Pelaksanaan Konseling Teman Sebaya

Efektivitas pelaksanaan konseling teman sebaya dilihat dari frekuensi dan intensistas terjadinya proses konseling diantara teman sebaya, dan atau proses reveral dari konselor sebaya kepada konselor ahli. Selain itu, munculnya sahabat yang hangat, penuh perhatian, tulus membantu, tulus memberikan dukungan saat menghadapi situasi yang sulit, serta dapat dipercaya juga merupakan indikator keberhasilan pelaksanaan konseling teman sebaya. Indikator tersebut, meningkatnya skor resiliensi anak yang diukur melalui resiliensi inventori juga menjadi indikator keberhasilan.

Evaluasi dilakukan melalui refleksi baik perorangan maupun kelompok, dan pengamatan terhadap proses interaksi yang terjadi, baik dalam forum- forum yang sengaja didesain demi munculnya interaksi interpersonal antar anak, maupun dalam berbagai kesempatan spontan selama anak beraktivitas. Selain pendekatan di atas, Dougherty dan Taylor (dalam Hunainah, 2012) juga menyarankan agar mengevaluasi efektivitas konseling sebaya dengan menganalisis data yang ada, misalnya jumlah konseli yang meminta bantuan pada "konselor" sebaya atau konselor ahli, konsistensi "konselor" sebaya dalam memberikan layanan bantuan kepada teman sebayanya, atau melalui wawancara informal dengan guru, orang tua, atau staf administrasi.

\section{Metodelogi Penelitian}

Penelitian ini merupakan penelitian lapangan (field research). dengan pendekatan kualitatif deskriptif analitik. Alasan pemilihan metode ini adalah karena penelitian bermaksud untuk mendeskrepsikan secara komprehensif, holistik, integratif dan mendalam tentang suatu gejala, peristiwa, kejadian yang terjadi pada saat sekarang yang 
berhubungan langsung dengan obyek penelitian. Melalui metode ini, diharapkan akan memperoleh pemahaman dan penafsiran yang mendalam mengenai makna dan data yang ada di lapangan untuk kemudian dianalisis dan ditemukan solusi atas masalah yang ditemukan.

Dalam pengumpulan data ini penulis berusaha untuk dapat memilih dan menggunakan metode pengumpulan data yang sesuai dengan permasaahan yang akan dipecahkan. Adapun teknik yang digunakan dalam penelitian ini adalah observasi. Metode ini digunakan untuk mengetahui informasi mengenai gambaran umum sekolah, meliputi letak geografis, sarana prasarana sekolah, mengamati kegiatan yang dilakukan, mencatat menganalisis dan selanjutnya membuat kesimpulan tentang bagaimana proses konseling sebaya (peer counseling) dalam mengentaskan masalah siswa di MAN 2 Yogyakarta. Hal ini dilakukan guna mendapatkan informasi yang relevan dengan topik penelitian ini.

Wawancara atau interview adalah sebuah dialog yang dilakukan oleh pewawancara untuk memperoleh informasi dari terwawancara (interviewer). Teknik yang digunakan penulis dalam interview ini adalah interview bebas terpimpin, dimana pewawancara bebas menanyakan apa saja yang ingin ditanyakan. Dan metode dokumentasi adalah cara pengumpulan data melalui barang-barang tertulis seperti: buku-buku, majalah, peraturan-peraturan, catatan harian dan sebagainya.

\section{Hasil penelitian dan pembahasan}

Mengacu pada teori Mamarrisinin dalam pembahasan kajian teori permasalahan siswa yang terjadi di MAN Yogyakarta II dikelompokkan sebagai berikut: konflik diri, masalah berupa pertentangan yang dialami individu baik dengan dirinya sendiri maupun orang lain, seperti yang 
terangkum pada masalah pribadi siswa. Kurang percaya diri, masalah ini sering dialami siswa yang memiliki citra diri yang negatif atau rendah tentang dirinya sendiri. Hal ini ditunjukkan dengan adanya bukti pencapaian angka kurang percaya diri siswa di MAN Yogyakarta II mencapai 45,83\%. Bergantung pada orang lain, masalah ini erat kaitannya dengan kurang percaya diri. Siswa demikian sulit berkembang karena tidak berani membuat keputusan untuk dirinya sendiri dan selalu menunggu orang lain untuk bertindak dalam segala hal. Hal ini ditunjukkan dengan adanya bukti pencapaian angka kurang percaya diri siswa mencapai 45,83\% dan negatif thinking 4,17\%.

Kurang menguasai keterampilan yang diperlukan, merupakan masalah yang banyak dialami siswa. Siswa yang tidak punya teman akrab karena tidak menguasai ketrampilan bergaul yang dapat diterima teman-temannya. Hal ini sesuai dengan permasalah siswa di MAN Yogyakarta II terkait dengan masalah pribadi yang terdiri dari kurang pergaulan, tertutup, pendiam, sering merasa sangat berbeda dengan orang lain, merasa tidak ada orang yang mengerti selain keluarga. Adapun yang terkait dengan masalah sosial seperti: sulit beradaptasi dengan lingkungan, sulit berkenalan dengan orang baru, sulit percaya dengan orang lain, sulit bercanda, dan tidak punya teman dekat. Kurang informasi, merupakan situasi masalah dimana siswa yang mengalaminya hanya memiliki sedikit informasi, yang tidak lengkap atau tidak punya keterangan sama sekali tentang sesuatu yang diperlukan. Seperti yang sudah dijelaskan sebelumnya, pribadi yang kurang informasi disebabkan karena pribadi tersebut kurang bergaul seperti penuturan siswa MAN Yogyakarta II inisial A sebagai berikut: "Saya suka ketenangan jadi saya memilih menyendiri dari pada bergaul dengan teman-teman, di rumah pun saya jarang maen ke tetangga, dan jarang keluar rumah, saya lebih 
asik maen game dan nonton televisi". Dengan demikian berarti seseorang yang kurang informasi bisa berakibat pada pribadi yang mempunyai mental yang kurang sehat, karena tidak menggunakan kemampuan yang dimilikinya dengan sebaik mungkin. Kecemasan dalam menentukan pilihan, merupakan masalah dimana siswa tidak ada pilihan yang diambil karena terpaku pada keadaan yang dirasakannya aman. Hal ini dikategorikan siswa yang mengalami masalah karir seperti masih suka bersenang-senang, belum memmiliki cita-cita, dan belum menemukan potensi diri.

Proses konseling dalam menuntaskan masalah siswa di MAN Yogyakarta II dilakukan dengan menggunakan alat bantu berupa konseling sebaya (peer counseling). Konseling sebaya (peer counseling) yang berlangsung di MAN Yogyakarta II mampu melakukan proses konseling dengan baik sesuai dengan teori yang dijelaskan pada bab II terkait dengan keterampilan dan praktek konselor sebaya. Upaya yang dilakukan konselor sebaya (peer counseling) dalam menuntaskan masalah aitu konselor mengadakan pertemuan dengan siswa (konseli), pada saat awal proses konseling berlangsung konselor menerima konseli dengan terbuka dan hangat, konselor mendorong (konseli) untuk mengungkapkan perasaannya dengan bebas yang berkenaan dengan segala permasalahan yang sedang dihadapi, konselor mengafirmasi perasaan konseli dengan bahasa verbal maupun nonverbal, seperti memegang pundaknya, pandangan yang fokus dan penguatan kata-kata, kemudian melakukan konfrontasi dan penguatan.

Hal ini bertujuan untuk mengetahui perasaan konseli yang sebenarnya. Seperti ucapan konselor sebaya, "anda berkata bahwa anda pemalu, lantas apakah anda tidak mempunyai teman?". Mengklarifikasi beberapa perasaan negatif maupun positif, contoh perasaan negatif 
seperti: tidak percaya diri, tidak bisa menerima kenyataan. Sedangan contoh perasaan positif seperti: ingin bersikap positif, berani,tanggung jawab dll. Adakalanya konselor menanyakan kepada konseli langkah pemecahan menurutnya pribadi. Namun, adakalanya memberikan fedback pernyataan jika konseli bingung dalam pemecahan masalahnya. Dalam proses konseling kesadaran diri sangatlah penting. kesadaran diri merupakan langkah pertama untuk memahami diri dan menentukan pilihan apakah seseorang perlu untuk memahami diri dan menentukan pilihan?, apakah seseorang perlu mengubah pola perilaku yang sudah ada agar lebih efektif?. Pengungkapan diri disamping membantu individu untuk mengenali dirinya sendiri juga sekaligus membimbing ke arah tujuan hidup seperti contoh saya ingin menjadi sosok seperti siapa? Bagaimana caranya untuk mewujudkannya?. Artinya, setelah menyadari kelemahan dan kelebihannya, maka seseorang dibimbing untuk menentukan tujuan dan harapan dalam hidupnya.

Berikut ini ungkapan beberapa konseli selama mengikuti proses konseling sebaya (peer counseling). Salah satu konseli dalam proses konseling mengungkapkan sebagai berikut: " Saya merasa tidak selevel dengan teman-teman saya, baik dari segi kepintaran, organisasi, dan kekayaan. Selain itu, saya merasa teman- teman saya tidak peduli dengan keberadaan saya. Apakah pikiran itu hanya prasangka saya saja?". Salah satu contoh ungkapan konseli pada waktu membangun harapan, ketika konseli mengalami kesulitan untuk bersikap asertif. Melalui proses umpan balik dalam konseling, pada saat pemberian informasi baru dan motivasi, konseli mengatakan bahwa "saya akan lebih menghargai kemampuan yang saya miliki karena mulai sekarang saya tahu bahwa setiap manusia memiliki kemampuan yang berbeda-beda". 
Konseli berikut ini mengalami keadaan yang sebaliknya dengan konseli yang pertama yaitu lebih suka bicara to the point. Konseli mengatakan "saya lebih suka bicara to the point dan akan merasa lucu ketika mencoba untuk berbasa-basi. Berdasarkan informasi dari teman sekelasnya konseli merupakan tipikal orang yang tertutup, pendiam dan keras kepala. Menurut konseli sikap tersebut sudah terbentuk sejak kecil dari keluarganya dan sekarang ini dirasakan konseli sebagai masalah. Untuk masalah ini konselor memberikan rangsangan berupa refleksi diri yang bertujuan untuk mengenal dirinya sendiri, orang lain dan tujuannya di masa mendatang. Berawal dari keinginannya untuk berubah dan belajar berbasa-basi inilah konseli curhat kepada konselor sebaya (peer counseling). Selama proses konseling konseli menyatakan "saya akan mencoba ramah, tersenyum, berbicara tidak to the point, memperhatikan orang lain, dan melunakkan pola pikir saya yang kaku. Hal ini salah satu bukti adanya self-knowladge, self-insight yang sangat berguna dalam membangun pribadi konseli menjadi lebih baik".

Memberikan motivasi juga dilakukan konselor sebaya (peer counseling) dalam memberikan dorongan atau ide kepada konseli dengan bahasa baik dan halus. Adapun cara yang dilakukan konselor sebaya (peer counseling) dalam memberikan masukan terhadap konseli dalam proses konseling yaitu memotivasi. Konselor meyakinkan pribadi konseli bahwa konseli memiliki kemampuan untuk menyelesaikan masalah yang dihadapinya dengan baik. Contoh: seluruh manusia memiliki kemampuan begitu juga konseli, alangkah senangnya jika konseli mampu menyelesaikan tugas secara mandiri tanpa mencontek lagi, saya yakin konseli bisa karena konseli memiliki potensi. Memberikan reward adalah sebagai usaha konselor untuk meyakinkan konseli agar konseli percaya diri dengan kemampuannya. Pujian dapat 
berbentuk verbal maupun nonverbal. Seperti menepuk bahu konseli yang mengindikasikan penghargaan.

\section{Simpulan}

Berdasarkan penelitian di lapangan dapat diambil kesimpulan sebagai berikut: proses pelaksanaan konseling sebaya (peer counseling) di MAN Yogyakarta II dilakukan melalui tiga tahap sebagai berikut: pemilihan calon "konselor" sebaya, pembekalan calon "konselor" sebaya, dan pengorganisasian pelaksanaan konseling sebaya

Faktor pendukung dan penghambat efektivitas konseling sebaya (peer counseling) dalam menuntaskan masalah siswa MAN Yogyakarta II yaitu: faktor pendukung konseling sebaya (peer counseling) adalah adanya kesadaran dari siswa untuk berkonsultasi kepada konselor sebaya, adanya kerja sama yang baik antara konselor sebaya dengan pihak lain seperti guru (BK), kepala sekolah, guru kelas, guru mata pelajaran dan organisasi siswa, peraturan sekolah yang tegas dapat meminimalisir pelanggaran siswa dan kerja sama yang baik antara sekolah dengan BKKBN, BNN, dan BKBI untuk mengoptimalkan layanan konseling sebaya (peer counseling) dalam menuntaskan masalah siswa.

Faktor penghambat konseling sebaya (peer counseling) adalah kurangnya kerjasama dan partisipasi dari pihak sekolah dengan pihakpihak yang terkait pelatihan konseling sebaya (peer counseling) dalam membantu menuntaskan masalah siswa, terbatasnya waktu layanan konseling sebaya, terbatasnya keterampilan konselor sebaya dalam menangani permasalahan siswa dan fasilitas sarana dan prasarana konseling kurang lengkap.

Adapun sarannya adalah sebagai berikut: bagi kepala sekolah MAN Yogyakarta II dari hasil observasi dan wawancara peneliti dengan 
guru (BK), konselor sebaya, konseli, dan siswa, bahwa konseling sebaya (peer counseling) perlu segera di legalkan, untuk itu pihak sekolah perlu segera melengkapi sarana dan prasaranan baik dari (BK) maupun konseling sebaya (peer counseling) demi kelancaran layanan dan kemajuan sekolah kedepannya. Sekolah hendaknya memberikan jadwal atau waktu khusus bagi bimbingan dan konseling agar program (BK) dan konseling sebaya (peer counseling) dapat terealisasikan dengan optimal sehingga (BK) dan konseling sebaya (peer counseling) menjadi bagaian yang urgen dalam membantu siswa. Bagi konseling sebaya (peer counseling) dan guru (BK) harus meningkatkan kinerja, lebih kreatif, inovatif lagi dalam memberikan bimbingan dan mengadakan koordinasi yang lebih baik lagi dengan berbagai pihak yang terkait. Mempertahankan kerja sama yang baik antar anggota, guru kelas, guru mata pelajaran, orangtua siswa, dan kesiswaan agar siswa bisa lebih mandiri dan dapat menyesuaikan diri dengan cepat di lingkuangan baru. Bagi wali kelas, guru mata pelajaran dan karyawan hendaknya selalu berupaya untuk aktif melaksanakan tugas (BK) sesuai dengan yang telah ditetapkan. Bagi para siswa untuk selalu semangat dalam menuntut ilmu dan mematuhi aturan yang berlaku di MAN Yogyakarta II agar mendapatkan kenyamanan dalam proses belajar.

\section{DaftarPustaka}

Erhamwilda. (2011). Peningkatan Kompetensi Intrapersonal Siswa SMK melalui Model Konseling Sebaya, Bandung: Universitas Islam Bandung.

Erhamwilda, (2012). Model Hipotetik Peer Counseling dengan Pendidikan Reality Theraphy untuk Siswa SLTA (Satu Inovasi Bagi Layanan Konseling di Sekolah). Jurnal BK Ta'dib, 15, (2). 
Busri, E. (2013). Konseling Teman Sebaya pada Remaja di Era Globalisasi, Pontianak: Universitas Tanjungpura.

Mishayati, E. R. (2013). "Kontribusi Pesantren Dalam Membantu Mengatasi Masalah-masalah Santriwati Pondok Pesantren Nurul Ummah Putri Yogyakarta", Tesis, Yogyakarta, Pascasarjana UIN Sunan Kalijaga.

Hunainah. (2011). Teori dan Implementasi Model Konseling Sebaya, Bandung: Rizki Pres.

Hunainah. (2012). Bimbingan Teknis Implementasi Model Konseling Sebaya, Bandung: Rizki Press.

Suraneta, K. (2013). Pengembangan Model Tutor Bimbingan Konseling Sebaya (peer counseling) untuk Mengatasi Masalah Mahasiswa Universitas Pendidikan UNDIKSHA. Bali: Universitas Pendidikan Ganesa.

Kan, P. V. (1996). Peer Counseling in Explanation. [Online]. Tersedia: http://www.peercounseling.com. Akses 22 November 2014 Lestariningsih. (2009). Upaya Meningkatkan Resiliensi melalui Pelaksanaan Pelatihan Peer Counseling pada Siswa, Semarang: IKIP.

Tohirin. (2009). Bimbingan dan Konseling Di Sekolah Dan Madrasah (Berbasis Integrasi), Jakarta: Raja Grafindo Persada.

Wibowo, M. E. (1986). Konseling di Sekolah, Semarang: Fakultas Ilmu Pendidikan IKIP.

Erlinasari, N. (2014). Peran Bimbingan Konseling dalam Membantu Menyelesaikan Masalah yang Dihadapi Siswa Akselerasi. (Studi Pada SMA Muhammadiah 1 Yogyakarta). Tesis, Yogyakarta: Pascasarjana UIN Sunan Kalijaga. 
Sukardi, D. K. (2000). Pengantar Pelaksanaan Program Bimbingan dan Konseling di Sekolah, Jakarta: PT Rineka Cipta.

Willis, Sofyan S. 2010. Remaja dan Masalahnya, Mengupas Berbagai Bentuk Kenakalan Remaja Narkoba, Free Sex dan Pemecahannya. Bandung: Alfabeta.

Varenhorst, B. (1984). Peer Counseling: Past Promises, Current Status, and Future Directions. Handbook of Counseling Psychology. New York: University of Minnesota.

Tindall, J. D., \& Gray, H. D. (1985). Peer Counseling: In-Depth Look at Training Peer Helpers. Muncie: Accelerated Development Inc.

Suranata, K. (2013). Pengembangan Model Tutor Bimbingan Konseling Sebaya (Peer Counseling) untuk Mengatasi Masalah Mahasiswa Fakultas Ilmu Pendidikan Undiksha. Jurnal Pendidikan Indonesia, 2, $255-263$. https://ejournal.undiksha.ac.id/index.php/JPI/article/view/21 70

Suwarjo. (2008). Pedoman Konseling Teman Sebaya Untuk Pengembangan Resiliensi. Makalah disajikan Seminar Pengembangan Ilmu Pendidikan Fakultas Ilmu Pendidikan Universitas Negeri Yogyakarta. staff.uny.ac.id/sites/default/files/penelitian/Suwarjo,\%20M.Si.,\% 20Dr.\%20/Peer\%20Couns\%20\&\%20Resiliensi\%20Siswa.pdf 